WSRC-MS-92-345

\title{
MATERIALS EVALUATION PROGRAMS AT THE DEFENSE WASTE PROCESSING FACILITY
}

by J.T.Gee

Westinghouse Savannah River Company

Savannah River Site

Aiken, South Carolina 29808

WSRC-MS $--92-345$

DE93 006161

D. C. Iverson

D. F. Bickford

A paper proposed for Presentation/Publication at the Corrosion '93

New Orleans, LA

03/07-12/93

This paper was prepared in connection with work done under Contract No. DE-AC09-89SR18035 with the U.S. Department of Energy. By acceptance of this paper, the publisher and/or recipient acknowledges the U. S. Government's right to retain a nonexclusive, royalty-free license in and to any copyright covering this paper, along with the it to reproduce and to authorize others to reproduce all or part of the copyrighted paper. 


\section{DISCLAIMER}

This report was prepared as an account of work sponsored by an agency of the United States Government. Neither the United States Government nor any agency thereof, nor any of their employees, makes any warranty, express or implied, or assumes any legal liability or responsibility for the accuracy, completeness, or usefulness of any information, apparatus, product, or process disclosed, or represents that its use would not infringe privarely owned rights. Reference herein to any specific commercial product, process, or service by trade name, trademark, manufacturer, or otherwise does not necessarily constitute or imply its endorsement, recommendation, or favoring by the United States Government or any agency thereof. The views and opinions of authors expressed herein do not necessarily state or reflect those of the United States Government or any agency thereof.

This report has been reproduced directly from the best available copy.

Available to DOE and DOE contractors from the Office of Scientific and Technical Information, P.O. Box 62, Oak Ridge, TN 37831; prices available from (615) 576-8401, FTS 626-8401.

Available to the public from the National Technical Information Service, U.S. Department of Commerce, 5285 Port Royal Rd, Springfield, VA 22161. 


\title{
MATERIALS EVALUATION PROGRAMS AT
}

\section{THE DEFENSE WASTE PROCESSING FACILITY}

\author{
J. T. Gee, D. C. Iverson, and D. F. Bickford \\ Westinghouse Savannah River Company \\ Savannah River Site \\ Aiken, SC 29808
}

\begin{abstract}
The Savannah River Site (SRS) has been operating a nuclear fuel cycle since the 1950s to produce nuclear materials in support of the national defense effort. About 83 million gallons of high-level waste produced since operations began has been consolidated by evaporation into 33 million gallons at the waste tank farm. The Department of Energy authorized the construction of the Defense Waste Processing Facility (DWPF), the function of which is to immobilize the waste as a durable borosilicate glass contained in stainless steel canisters prior to the placement of the canisters in a federal repository. The DWPF is now mechanically complete and is undergoing commissioning and run-in activities. A brief description of the DWPF process is provided.

DWPF startup testing, using simulated non-radioactive feeds, is scheduled to begin in November 1992 with radioactive operation scheduled to begin in May 1994. A materials evaluation program has been developed to investigate erosion/corrosion of remotely operated DWPF equipment. This materials evaluation is being performed during startup testing and will be completed in late 1993. A novel inspection device has been developed for viewing the interior of the glass melter while at operating temperature. The condition of "as-built" equipmeni inas been evaluated using several non-destructive techniques and will be reevaluated after startup testing completion to validate materials selection, to establish wear/corrosion rates, and to predict equipment service lives.
\end{abstract}

Keywords: high-level waste, Defense Waste Processing Facility, borosilicate glass, melter, erosion, corrosion

\section{INTRODUCTION}

The U.S. Department of Energy's Savannah River Site has operated a nuclear fuel cycle to manufacture defense nuclear materials since the early 1950 s. The processing of irradiated fuels and targets to recover the desired isotopes has resulted in a mixed high-level nuclear waste stream containing a variety of radioisotopes. During this time, approximately 83 million gallons of high-level waste has been produced. To conserve storage space, the waste solutions have been concentrated to approximately 33 million gallons by evaporation. The waste is stored in alkaline form in 1.3-million-galion carbon steel tanks located at the SRS separations areas. Most metal ions in the waste are precipitated as hydroxides while the alkali metals stay in solution. Waste processing has resulted in three discrete forms in the waste tanks: sludge, salt cake, and saturated salt solution. Most of the radioactive components are in the sludge except cesium-137 and small amounts of plutonium and strontium, which are found in the salt cake and supernate. 


\section{BACKGROUND}

\section{DWPF Process Description}

Waste Tank Farm Processing. To prepare the waste for transfer to the DWPF, waste tank farm processing includes dissolving excess aluminum from the sludge with concentrated sodium hydroxide, followed by sludge washing to remove excess salt. Salt cake is dissolved and the resultant solution, along with sludge washing effluent, is decontaminated via an in-tank precipitation process. ${ }^{1}$ This precipitation process uses sodium tetraphenyl borate to precipitate cesium and potassium from the solution and also uses sodium titanate to adsorb plutonium and strontium. These products are then filtered from the salt solution. Washed sludge, precipitate product, and decontaminated salt solution are the feeds to the DWPF system.

As shown in Figure 1, the DWPF process includes several major activities. These include: disposal of decontaminated salt solution as saltstone ${ }^{2}$, hydrolysis of the precipitate generated during salt decontamination, chemical reduction of mercury from the waste sludge, melter feed preparation, glass melting, canister filling, decontamination and sealing, and melter offgas decontamination. These process steps are described in further detail in later paragraphs.

Saltstone. Filtered decontaminated salt solution is disposed of as a cement grout called saltstone. Approximately 115 million gallons of this grout will be produced, which will contain less than $0.01 \%$ of the original waste activity. (A process diagram for the saltstone process is shown in Figure 2.) The dry ingredients for saltstone production are flyash ( $47 \mathrm{wt} \%$ ), furnace slag $(47 \mathrm{wt} \%)$, and class $\mathrm{H}$ Portland cement ( $6 \mathrm{wt} \%)$. These materials are mixed in an air blender, then pneumatically transferred to a pre-mix feed bin on top of the processing building. The pre-mix is then fed to a mixer where it is blended with decontaminated salt solution. The resultant grout is then pumped io one of the concrete vaults that are $600 \mathrm{ft}$ long by $100 \mathrm{ft}$ wide by $25 \mathrm{ft}$ high. At design throughput, 9 million gallons of decontaminated salt solution will be processed into 70,000 yds of grout per year. When filled, each vault will be capped with a layer of clean grout, then covered with a clay cap, soil, and grass. Wells surrounding the saltstone vaults will be monitored for possible radiological releases from the saltstone.

Precipitate Hydrolysis. The precipitate products of the salt solution decontamination process (cesium and potassium tetraphenyl borate) must be decomposed before entering the melter feed stream to minimize aromatic hydrocarbons fed to the glass melter. This decomposition is accomplished by an acid hydrolysis process. ${ }^{3}$ Because nitrite corrosion inhibitor, which has been added to the precipitate product at the tank farm, can interfere with the hydrolysis reaction, it is destroyed before beginning hydrolysis by adding hydroxylamine nitrate (HAN). A process diagram for acid hydrolysis is shown in Figure 3. First, formic acid and HAN are added to the heel in the precipitate reactor (PR), then precipitate from the tank farm is metered in at approximately $20 \mathrm{gpm}$. During this nitrite destruction step, the ternperature is maintained at approximately $50^{\circ} \mathrm{C}$. After completing the precipitate feed step, a copper catalyst is added to the reactor, the contents are heated to boiling, and refluxed for five hours to complete the hydrolysis. Heavy organics are steam-stripped into a condenser/decanter where aqueous products are recycled to the PR. The organic product is transferred to an organic evaporator for additional decontamination to produce an organic prcduct with activity less than $1000 \mathrm{~d} / \mathrm{m} / \mathrm{ml}$. This material is transferred to the organic waste storage tank (OWST), which will hold approximately three years of production output. The organic material will be eventually destroyed in an incinerator facility.

Melter Feed Preparation. After organic removal, the cesium-bearing aqueous stream from acid hydrolysis is combined with washed sludge from the waste tank farm in the sludge receipt and adjustment tank (SRAT). Formic acid is added to destroy nitrite and carbonate and to adjust the redox state of waste components before glass melting. The formic acid also chemically reduces mercuric oxide in the sludge to metallic mercury, which is removed from the system by steam distillation. The adjusted sludge is transferred to the slurry mix evaporator (SME) where powdered glass frit slurry is added and the resultant slurry is concentrated to approximately $50 \mathrm{wt} \%$ solids for transfer to the melter feed tank. The glass frit is a hard, sharp, angular material that is potentially abrasive to process piping and equipment. The feed preparation process is shown in Figure 4.

The feed batch composition is determined by the product composition control system (PCCS). ${ }^{4}$ PCCS is a statistically based system that determines acceptable blends of sludge, hydrolysis product, and frit while taking into account uncertainty associated with tank-level measurement, sampling, analytical error, and other errors associated with the feed preparation process. The system uses numeric models of waste glass properties as a function of composition to predict the properties and compare them to acceptable limits. The system also attempts to maximize waste loading while satisfying glass durability and processability criteria. 
Glass Melting. Vitrification of the frit-waste slurry is accomplished in a joule-heated ceramic lined melter. (See Figure 5.) The slurry is continuously fed to the glass melter through two water-cooled feed tubes at a rate corresponding to 228 pounds per hour of glass production. The slurry drops directly onto the molten glass surface where it dries, forms a semi-solid feed pile, then melts from the bottom, forming borosilicate waste glass. The glass homogenizes as a result of thermal convection currents in the melter, then exits through a throat located near the bottom of the melter, passes through a heated riser section, and finally drops through a pour spout into a stainless steel canister. ${ }^{5}$ (See Figure 6.) The glass temperature in the melter is maintained at approximately $1150^{\circ} \mathrm{C}$ by applying power through two pairs of diametrically opposed electrodes. Eight resistance heaters supply additional power in the plenum of the melter to help evaporate water and to maintain the plenum temperature above the autoignition temperature of the organics entering the melter. Upon filling, canisters are temporarily sealed, decontaminated by frit slurry blasting, welded shut, then stored in an interim storage facility pending designation of a federal repository.

Melter Offgas Treatment. The melter offgas is treated through a quencher and a series of scrubbers and filters to remove heat, water, and particulates. ${ }^{6}$ Two identical offgas systems are present to minimize the probability of a loss of offgas decontamination capability. Figure 7 shows the offgas treatment diagram. The offgas exits the melter via a film cooler that injects steam and air to prevent deposition of hot entrained particles in the offgas exit line. The offgas then enters a venturi quencher located immediately adjacent to the melter where heat is removed and the majority of the steam is condensed. It then passes through the offgas condensate tank and to two steam atomized scrubbers in series, which remove more than $98 \%$ of the particulates. The scrubbed offgas is then chilled to $10^{\circ} \mathrm{C}$ in a condenser for additional water and mercury removal, passed through a high efficiency mist eliminator, reheated, and then passed through two stages of high efficiency particulate air (HEPA) filters. The offgas then passes through the exhauster, the DWPF sand filter, then exits the facility stack. The offgas treatment system is designed to achieve an overall decontamination factor of approximately $8.0 \times 10^{8}$.

\section{Startup Test Program Description}

Before beginning radioactive operation of the DWPF, overall functionality of the facility must be demonstrated. This functional status check includes: (1) a demonstration of the ability to produce a glass product that meets all processing and waste acceptance criteria, (2) check-out and run-in of all equipment (including remote operation and maintenance), (3) demonstration that highly radioactive materials can be safely handled in the facility, and (4) demonstration that DWPF personnel are capable of safe, efficient operation of the facility. To accomplish these goals, a startup test program ${ }^{7}$ has been developed that is modeled after those programs used for successfully start up commercial nuclear reactor facilities.

The startup program consists of a series of tests that are performed over about a two-year period that are designed to demonstrate the process and product. Preliminary or commissioning tests have been performed to ensure that facility support systems are ready to support the main process activities. These commissioning tests are followed by cold chemical runs ${ }^{8}$ in which all DWPF systems are operated with simulated (non-radioactive) feeds. Cold chemical runs (scheduled to begin in November of 1992) include five melting tests, which will be used to establish plant operating parameters and to confirm process and equipment acceptability.

\section{DWPF MATERIALS EVALUATION PROGRAM DESCRIPTION}

Startup test programs have been developed to evaluate erosion/corrosion of the remotely operated DWPF equipment during non-radioactive chemical testing scheduled to end in late 1993.9,10 Work is divided into three parts. The first includes establishing the "as-built" condition of equipment. This includes measurement of wall thickness in potential wear spots, radiography of selected areas, and visual inspection. Second, after the initial non-radioactive chemical runs have been completed, an erosion evaluation will be performed to check for extensive erosion problems before introducing mercury compounds into the system. This permits a more thorough inspection to be performed without the health and environmental concerns associated with mercury. Finally, after introduction of mercury to the system, a more general erosion/corrosion evaluation will be performed on selected equipment for comparison to "as-built" condition. This will be performed after mercury chemical feed runs to evaluate the effect of mercury on system corrosion.

This paper will focus on the methodology used to perform the erosion/corrosion evaluation. Techniques that were used (work completed) to establish the condition of "as-built" equipment will be described. But first the reasons why the DWPF is concerned about erosion/corrosion will be discussed and some of the techniques that were used to mitigate the problem will be described. 


\section{Erosion/Corrosion Concerns at Defense Waste Processing Facility}

Design of DWPF Facility to Minimize Erosion/Corrosion Concerns. Because the DWPF will process highly radioactive materials, the facility was designed to be remotely operated. This allows little hands-on maintenance. Design requirements for permanent facility piping required a 20-year life. All major equipment has to be remotely maintained or must be removed from the cell for decontamination before repair, replacement, or disposal. Therefore, equipment depends on gasketed connections for mating be tween equipment and transfer lines rather than field welds. These connections make equipment especially sensitive to crevice corrosion and pitting. The need to minimize the quantity of waste generated by the facility has also impacted the DWPF design. Wastes are minimized by recycling process streams and severely restricting the use of corrosion inhibitors.

Based on these points, the DWPF design is extremely sensitive to erosion/corrosion problems. The design includes conservative selection of materials of construction based on extensive laboratory and pilot testing. ' Much of the primary chemical process equipment was fabricated from Hastelloy C-276@ (UNS No. N10276), which is highly resistant to localized corrosion. Special precautions were taken to reduce the risk of intergranular attack for most processing equipment. These precautions included controlled welding and heat treatment procedures, restrictions on carbon content (below "L" alloy requirements), and requiring "Corrosion Evaluation" certification. Lines containing glass frit and process slurry were sized to minimize velocity and were designed with long radius bends to reduce erosion concerns. Underground waste transfer lines were designed with secondary containment (e. g., protective jacket pipe) and impressed current cathodic protection to further mitigate corrosion concerns.

Erosion/Corrosion Concerns (Except Glass Melter). Receipt and concentration of sludge formed during caustic neutralization of high-level waste presents unique problems in selecting materials of construction for DWPF process equipment. Halides, nitrates, nitrites, sulfates, and phosphates that are concentrated during waste storage remain relatively unreactive in the alkaline storage environment. The gelatinous hydroxide sludge includes iron, copper, and mercury, which can contribute to crevice corrosion and pitting. The vitrification process requires reacidfication of the concentrated sludge, which typically results in a pH of 3 with several thousand parts per million (ppm) chloride and fluoride.

The two most corrosive areas of the process were determined to be melter feed preparation and melter offgas condensate. The melter feed preparation zone includes the SRAT,SME, and melter feed tank (MFT). The condensers for these tanks were also included in this zone because pilot plant experience indicated that tank solutions could be forced up into the condensers and result in higher-than-expected temperatures. Tests run in boiling simulated process slurries resulted in selection of Alloy N10276 for equipment in this zone. Test experience in the full-scale SRAT/SME at the Savannah River Technology Center pilot plant confirmed that condensers could be exposed to tank solutions and that localized conditions of high wear occurred when glass frit was present.

Because of the presence of mercuric chloride, low $\mathrm{pH}$, and elevated temperatures, the most corrosive stream in the DWPF is the melter off gas condensate. To minimize water usage and waste generation, offgas condensate is used as a service liquid in the offgas quencher and steam atomized scrubbers. Offgas equipment subject to attack by condensate includes the quencher, offgas condensate tank (OGCT), steam atomized scrubbers, the high efficiency mist eliminator, and associated pumps and piping. For the purpose of materials selection, the system was divided into high and low temperature regions. Alloy N10276 was the material of choice for the low temperature region (less than $60^{\circ} \mathrm{C}$ ) . Allcor was selected for the quencher because of the slightly better performance than N10276 at higher temperatures. Based on SRTC testing for melter electrode materials, piping from the melter to the quencher, which operates above $300^{\circ} \mathrm{C}$ and is dry, is fabricated from Inconel 690ल) (UNS No. N06690).

Erosion of the floors of the process vessels containing glass frit is a concern, because wear has been evident near the support guides (for agitators) for the full-scale SRAT and SME at the SRTC pilot plant. ${ }^{15}$ Erosion has also been observed on the agitator blades for the same equipment. ${ }^{16}$

Hastelloy C-276 is a trademark of Haynes International, Kokomo, IN.

Allcorr is a trademark of Teledyne-Allvac, Monroe, NC.

Inconel and Inconel 690 are trademarks of Inco Alloys International, Huntington, WV. 
Slurried frit, SME product, and melter feed are particularly abrasive where disruption of the stream flow causes a jet to impinge on a pipe wall. Therefore, particular regard must be paid to the areas adjacent to welded elbows and joints in the sample lines for these streams. Because of these concerns, sample pumps transporting frit slurries will be operated longer than necessary for normal chemical run sampling, so that sufficient operating time (e. g., three years of equivalent service) is achieved in the pumps and in the permanent sample loop piping. The sample pumps are similar in construction to the main slurry transfer centrifugal pumps. The pumps are of cast Stellite-6 construction to resist the abrasive glass frit attack.

Erosion/Corrosion Concerns (Glass Melter). The DWPF glass melter was developed based on extensive lab and pilot scale testing. ${ }^{11,17}$ Monofrax K-30 is the reference glass contact refractory. While this refractory is expected to last the life of the melter (two-year design life), there is some concern that cracking and spalling may occur just above the melt line because of thermal shock. Alloy $\mathrm{N} 06690$ is the reference glass contact metal for melter fabrication. Uses include lid heaters, melter electrodes, riser heater, thermocouple protection tubes, and offgas piping. Alloy N06690 melts at approximately $1350^{\circ} \mathrm{C}$, so it is important to maintain melter operating temperatures below $1170^{\circ} \mathrm{C}$. With adequate temperature control, Alloy N06690 maintains sufficient creep resistance for the massive self-supporting melter electrode components. Pilot plant experience has indicated that Alloy N06690 will perform well in terms of erosion/corrosion, although sulfidation, oxidation, or both may be a concern in certain environments.

\section{Program Objectives}

The overall test objective is to evaluate the erosion/corrosion rates for remote DWPF equipment after extended non-radioactive operation. This testing is being done to demonstrate that the major pieces of provissing equipment have sufficient corrosion and abrasion resistance to achieve their design lives (20 years for permanent piping, two years for the melter, five years for major process equipment, and one year for easily changed equipment such as process jumpers).

Inspection of the majority of the melter feed preparation and melter offgas equipment is impractical because of time limitations and the complexity of the DWPF process equipment. Therefore, inspection is limited to selected areas (sce below), based on previous experience, to confirm the proper selection of materials for major equipment. The expectation is that some failures of isolated pieces of equipment will occur during cold runs, especially instruments with small corrosion allowances. Failed miscellaneous equipment will be examined in an effort to establish cause and corrective measures, but preference will be given to projecting the useful life of permaneni piping and major process vessels.

\section{RESULTS}

\section{Completed Program Activities}

Several support activities have been performed to support the materials evaluation program during DWPF cold chemical runs. These activities included the following:

Establishing Condition of "As-Built" Equipment.(1) Baseline thickness measurements and visual inspections of the DWPF critical process tanks and internal components have been performed. Ultrasonic thickness measurements were taken on tank floors, tank walls, heating and cooling coils, and upper and lower agitator blades. ${ }^{18-20}$ Photographs were taken of the interior of these process vessels to record the baseline appearance.

Portions of critical process piping including jumpers, transfer lines, and sample line recirculating loops were characterized using a combination of ultrasonic thickness measurements and radiography. This work focused on welded joints, bends, and elbows of the permanent piping system, where flow obstructions may lead to erosion.

Recirculating sample line pick-up points in the PR, SRAT,SME, and MFT were radiographed to establish their "asbuilt" condition. This included location, orientation, and finish of the entrance to the sample lines. Erosion in these lines may affect the representativeness of the slurry sample; therefore, monitoring their condition is essential.

Stellite-6 is a trademark of Haynes International, Kokomo, IN.

Monofrax and Monofrax K-3 are trademarks of Carborundum Co., Niagara Falls, NY.

(1) Note: Much of the baseline data collected to support the materials evaluation program was documented on 25 internal quality control condition reports. These reports are not listed separately in the Reference Section. 
The PR, SRAT, SME, and MFT liquid samplers were characterized to establish "as-built" condition. Valve and valve seat dimensions were recorded. The components were then reinstalled and radiographed to record the exact valve positions at startup. Wear on the inlet to the samplers may affect the accuracy of the samples.

Critical process pumps, which may be exposed to erosive or corrosive service, were characterized to establish their "as-built" condition. Wear parts were visually examined, dimensionally analyzed, and photographed to document their condition.

Limited video probe inspections were performed on selected tanks, vessels, and piping systems. This activity provided training on the use of the video probe and provides a useful video record on the condition of the equipment.

A novel water-cooled melter inspection device was developed at SRTC to permit inspection of the glass melter interior when it is in a hot idle mode. ${ }^{21}$ While operating, the melter glass temperature will be $1150^{\circ} \mathrm{C}$ and the plenum temperature will be approximately $700^{\circ} \mathrm{C}$. The inspection device has been designed to withstand this environment and will be used for later inspections after radioactive materials have been introduced. The inspection device is designed for remote installation and removal by overhead crane. The inspection device is capable of viewing (by video camera) much of the interior of the melter above the melt line. It allows a field of view of at least 18 inches $(0.45$ meters) square, with a capability to zoom in on an area as small as 3 inches $(0.08$ meters) square. The video record provides the azimuth and elevation of the view with respect to a given reference point during inspection. This reference point remains constant after removing and reinstalling the viewing device so that subsequent inspections may be accurately compared to the reference inspection. Preliminary testing of the melter inspection device (before melter heat up) is scheduled for November 1992. This testing will accomplish two goals. It will (1) allow confirmation that the inspection device will perform as designed; and (2) provide baseline inspection data to establish the "as-built" condition of the melter interior. This inspection will be used for comparison with data generated during later inspections.

Preparations for Cold Chemical Runs. A record keeping system has been developed to determine and record the speed and operating time for major agitators and process pumps. Such data will allow erosion/corrosion rates to be estimated on both realtime and number of batch cycles basis.

An analytical program has been established to determine the composition (primarily $\mathrm{pH}$ and ions) of simulated waste process streams. This program will be performed throughout cold chemical runs. The sample analyses will be used to compare observed corrosive conditions with those used in earlier laboratory corrosion tests to establish construction material requirements. Since these early tests largely defined the materials of construction, any change in the levels of corrosive agents could explain identified materials problems.

Corrosion coupon racks were installed in the OGCT, SRAT, PR, and the slurry mix evaporator condensate tank in both the liquid and vapor regions. The racks contain welded samples, galvanic couples, crevice, and stressed coupons for both process vessel materials of construction and back-up materials.

\section{Future Program Activities}

The following activities will be performed to support the DWPF materials evaluation program.

Planned Erosion Evaluation. After several of the cold run feed tests are performed, but before adding mercury compounds to the feed streams, an erosion evaluation will be performed. The intent of this test is to determine if serious erosion has occurred before adding the mercury. Mercury compounds and the associated health and environmental concerns make inspection efforts more difficult. Selected equipment exposed to glass frit slurries will be removed, inspected, and reinstalled. Equipment inspections will be given a priority based on where erosion was observed in the full-scale SRAT/SME pilot equipment developed at the SRTC. The back side of lower agitator blades and the tank floor located behind the cooling/heating coil support guides are of particular interest. Parts of the recirculating sample loops containing frit may be subject to similar wear and will be examined. Depending on the extent of the erosion, additional equipment may be inspected. Inspection techniques will include visual examination, photography, and ultrasonic thickness measurements. If the process tanks require inspection, either visual or video probe inspection techniques will be used. Radiography may be used on selected process lines if severe erosion is indicated.

Planned (Final) Erosion/Corrosion Evaluation. After the mercury feed runs are completed, the effects of corrosion will be evaluated using two different techniques. One approach is to examine selected process components to determine the extent of corrosive attack. Also, in situ corrosion coupons that were placed in four process tanks will be examined to document the rate of corrosion. Details are described below. 
The coils and agitators of selected process tanks will be removed and visually inspected to determine if localized erosion/corrosion has occurred. Ultrasonic thickness measurements will also be performed on these components. Combined erosion/corrosion rates will be calculated based on dimensional changes from the baseline condition. These rates will then be used to predict possible equipment life.

Visual inspection will be performed on the exterior of process vessels for leaks, cracks, or damage. Equipment will include major tanks, the melter offgas system, and portions of the process piping.

Video probe inspection of the interiors of selected process vessels (tanks, condensers, quencher) and selected process lines will be performed. The presence of deposits, scales, or other abnormalities will be noted. Deposits will be sampled and analyzed to determine possible impact on equipment life.

During the video probe inspections, selected interior welds will be examined for evidence of corrosion such as cracking or pitting. If significant evidence of weld corrosion is noted, a more thorough evaluation will be performed.

Selected process pumps will be removed, disassembled, and inspected. Wear parts will be examined for erosion/corrosion. If the erosion/corrosion is significant, rates will be calculated.

As noted previously, much of the critical process equipment was characterized using ultrasonic thickness measurements. This equipment will be reexamined after the cold runs using this technique. Differences between the baseline data and the measured wall thicknesses can be used to determine if significant erosion/corrosion has occurred, and to calculate combined erosion/corrosion rates.

Corrosion sample racks will be removed from the process tanks and evaluated at the end of the mercury feed runs. All racks will be inspected and photographed upon removal. Evaluation of individual coupons will be performed following guidelines stated in ASTM G-1, "Preparing, Cleaning, and Evaluation of Corrosion Test Specimens".

A more extensive corrosion coupon evaluation is being performed at the SRTC pilot facility. This work, with 20 different sample rack locations, will be used in conjunction with the present effort to evaluate DWPF materials of construction and to help to qualify alternate material candidates.

Melter Inspection During DWPF Cold Runs. This inspection will be performed using the melter inspection device described earlier. Note that the melter will contain $1150^{\circ} \mathrm{C}$ glass during this inspection. Based on prior Savannah River Site melter operating experience, the area of highest refractory wear is at or slightly below the normal melt line. Therefore, it will be necessary to lower the glass level to below that zone so that melter corrosion may be properly assessed. The refractory will be examined for cracking, spalling, or other damage.

An inspection of the Alloy N06690 components will also be performed. The general condition of the visible electrode surfaces will be evaluated to determine if excessive wear or structural deformation has occurred. The top head components in the lower temperature region of the melter may be at risk for sulfidation attack. This area will be visually checked using the inspection device and by removing selected components for visual inspection.

Results Expected From Materials Evaluation Program

It is not the intent of the erosion/corrosion studies to test against specific acceptance requirements for the process equipment. It is the intent of this work to use test results to determine the erosion/corrosion rates to the vessels and associated components under DWPF process conditions. These values can then be used to predict the life expectancy of the process equipment. By comparing these life expectancies against the design criteria, judgments about the suitability of the process equipment can be made. 
If projected life of any of the equipment is less than the design goal, then DWPF Operations must decide what corrective actions to take. These corrective actions may involve equipment or process modifications, replacement of selected components with those fabricated using alternate materials, or a design change for future equipment replacement.

\section{CONCLUSION}

The DWPF has a comprehensive materials evaluation program in place to evaluate erosion/corrosion of the remotely operated DWPF equipment during non-radioactive chemical testing ending in late 1993. The condition of "as-built" equipment has been evaluated using several non-destructive techniques, including a novel melter inspection device for high temperature inspection. Inspection will be repeated after non-radioactive chemical testing to validate materials of construction, to establish wear and corrosion rates, and to estimate equipment service lives.

\section{ACKNOWLEDGMENTS}

The authors wish to offer their appreciation to personnel of many organizations at the Savannah River Site that are assisting in the materials evaluation program. The scope of this program will require the combined talents and contributions from many different personnel and organizations. The information contained in this article was developed during the course of work under Contract No. DE-AC09-89SR 18035 with the U. S. Department of Energy.

\section{REFERENCES}

1. L. M. Lee and L. L. Kilpatrick, "A Precipitation Process for Supernate Dec'sntamination", E. I. Du Pont de Nemours \& Co., Savannah Piver Plant, DP-1636, 1982.

2. E. L. Wilhite, et al., "Saltcune Processing Startup at the Savannah River Plant," Pruceedings of the 10th Annual DOE Low-Level Waste Maragement Conference, Denver, Colorado, CCNF. - 880839 Session IV, 1988.

3. J. C. Marek, et al., "Defense Waste Processing Facility Nitrite-Destruction Precipitate Hydrolysis Process," presented at the International Symposium on Reprocessing and Waste Management, High Level/TRU Waste Technology Session \#50, 1988.

4. R. L. Postles and K. G. Brown, "The DWPF Product Composition Control System at Savannah River: Statistical Process Control Algorithm", WSRC-MS-91-104, Proceedings of the Fifth International Symposium on Ceramics in Nuclear and Hazardous Waste Management, Cincinnati, Ohio, 1991.

5. R. G. Baxter, "Defense Waste Processing Facility Wasteform and Canister Description", E. I. Du Pont de Nemours \& Co., Savannah River Plant, DP-16006, 1988.

6. C. T. Randall and D. M. Sabitino, "Offgas System for SRP DWPF", E. I. Du Pont de Nemours \& Co., Savannah River Plant, DP-MS-135, 1986.

7. H. H. Elder, "DWPF Startup Test Program”, Westinghouse Savannah River Co., OPS-DTD-890004, 1989.

8. J. A. Gentilucci, "Defense Waste Processing Facility Integrated Cold Runs", Waste Management '89, Proceedings of the Symposium on Waste Management, Tucson, Arizona, Vol. 1, 1989.

9. J. T. Gee, "Process Vessels Erosion/Corrosion Studies", Defense Waste Processing Facility Startup Test Plan DWPF-FA-04, Westinghouse Savannah River Co., June 29, 199?.

10. D. C. Iverson, "Melter Erosion Study”, Defense Waste Processing Facility Startup Test Plan DWPF-FA-05, Westinghouse Savannah River Co., August 15, 1990.

11. D. C. Iverson and D. F. Bickford, "Evaluation of Materials Performance in a Large Scale Glass Melter After Two Years of Vitrifying Simulated SRP Defense Waste", Materials Research Society Symposium Proceedings 44(1985), p. 839.

12. D. F. Bickford and R. A. Corbett, "Materials Selection for the Defense Waste Processing Facility", Corrosion of Nickel Based Alloys, R. C. Scarberry ed., ASM (1985). 
13. R. A. Corbett, D. F. Bickford, and W. S. Morrison, "Corrosion Evaluation of Alloys for Nuclear Waste Processing,", Materials Performance, 26, 2, (1987), p. 40.

14. D. F. Bickford, R. A. Corbett, and W. S. Morrison, "Test Methods for Selection of Materials of Construction for High-Level Radioactive Waste Vitrification", Ceramic Advances, 20 (1986), p. 53.

15. C. F. Jenkins and S. M. Nordwick, "SRAT/SME Components Wear Evaluation", Westinghouse Savannah River Co., EED870869, November 16, 1987.

16. C. F. Jenkins, "SRAT/SME Components Wear", Westinghouse Savannah River Co., EED870106, March 25, 1987.

17. F. H. Brown, et al., "Savannah River Laboratory's Operating Experience with Glass Melters", The Treatment and Handling of Radioactive Wastes, A. G. Blasewitz (ed.), Battelle Press, (1983).

18. S. M. Nordwick, “DWPF Reaction Vessels”, Westinghouse Savannah River Co., EED890173, February 2, 1989.

19. S. M. Nordwick, "New DWPF Reactor Vessels, Coils, and Agitators", Westinghouse Savannah River Co., EED881170, November 14, 1988.

20. S. M. Nordwick, "Precipitate Reactor Feed Tank and Precipitate Reactor", Westinghouse Savannah River Co., EED890179, January 24, 1990.

21. D. C. Iverson, “Basic Data Report, DWPF Melter Inspection Device (U)”, Westinghouse Savannah River Co., OPS-DTA-900003, February 1990. 

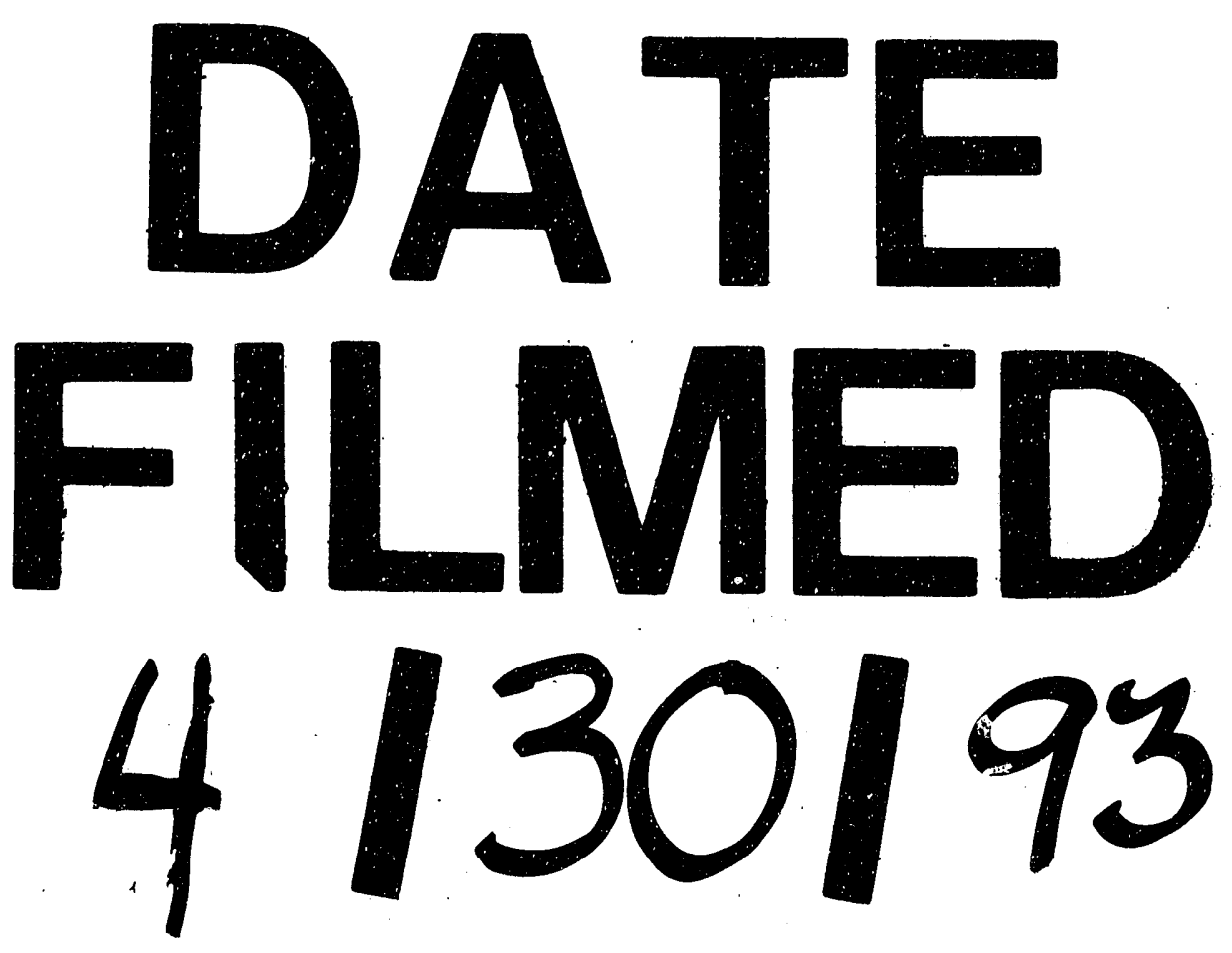
